\title{
Krzysztof Niźnik
}

Wrocław

\section{Okładka płytowa \\ czyli muzyka w otulinie plastyki}

Abstrakt: Okładka płytowa może być analizowana na trzech poziomach: jako opakowanie, źródło informacji oraz przedmiot o walorach artystycznych. Kolejność ta oddaje ewolucję sposobu jej postrzegania. Nie tracąc funkcji użytkowych, stała się obiektem ocen estetycznych. W tekście przyglądam się roli okładki w uzyskaniu przez wytwórnię płytową rozpoznawalności na rynku fonograficznym, na przykład za pomocą logo (Deutsche Grammophon), zespołu stałych i charakterystycznie rozmieszczonych elementów (For Tune) lub ogólnej koncepcji zdobniczej bez rygorystycznego określania szczegółowych rozwiązań (Blue Note). Ważnym narzędziem jest także wydawanie spójnych pod względem opracowania plastycznego serii płyt poświęconych wykonawcom, kompozytorom oraz stylom lub formom muzycznym. Istotnym zagadnieniem są również relacje między muzyką a towarzyszącym jej okładkom płytowym. Intuicja podpowiada, że mamy tutaj do czynienia z powinowactwem. W wypadku wielu okładek trudno jednak uzasadnić istnienie takiego związku. Znacznie częściej można mówić o wyraźnej przypadkowości zestawienia muzyka-okładka.

Słowa-klucze: okładka, płyta, wytwórnia płytowa, marketing, muzyka

Roztrząsanie na przełomie drugiej i trzeciej dekady XXI wieku zagadnienia okładek płytowych jest zajęciem niewątpliwie interesującym, ale też czynionym poniekąd poniewczasie. Od kilkunastu lat drastycznie spada bowiem sprzedaż płyt z muzyką ${ }^{1}$, żyjemy więc w schyłkowym okresie popularności tego nośnika komunikacji ${ }^{2}$. Jednak przez ponad stulecie było to główne narzędzie dystrybuo-

1 Zob. Już 100 mln odbiorców płaci za muzykę w internecie, https://www.legalnakultura.pl/pl/ czytelnia-kulturalna/badania-i-raporty/news/2483,100-mln-odbiorcow-placi-za-muzyke-w-internecie, 6.03.2017 (dostęp: 10.01.2021). Współcześnie główny sposób dystrybuowania nagrań muzycznych za pośrednictwem internetu to przede wszystkim udostępnianie możliwości odsłuchiwania muzyki w czasie realnym (streaming) oraz sprzedaż plików MP3 i — w coraz mniejszym zakresie - CD. O tych przemianach i ich wpływie na odbiór muzyki zob. S. Nożyński, M. Okólski, Muzyka bez nośnika? Chmury i strumienie oraz cyfra, taśmy i winyle $w$ walce o pierwostuch lub zapomnienie, „Przegląd Kulturoznawczy” 2019, nr 1, s. 51-67.

${ }^{2}$ Nastąpił wprawdzie wzrost popytu na płyty winylowe i jest to w tej chwili bodaj jedyny rozwijający się segment rynku wydawnictw muzycznych. Dotyczy to jednak niewielkiego grona nabywców-pasjonatów. Sprzedaż płyt winylowych należy analizować w porównaniu do płyt CD. 
wania muzyki. Wraz z taśmą magnetofonową tworzyły fundament rozwoju rynku muzycznego, a nawet bywały - wyraźnie jest to widoczne w wypadku rapu i hip-hopu - nieodzownym elementem dynamizującym powstawanie nowych odmian stylistycznych muzyki ${ }^{3}$. Już tylko $\mathrm{z}$ tego względu jest to ciekawy obszar do analizy. Mamy przecież do czynienia z całą dostępną współcześnie muzyką, czyli sferą ogromnie rozległą, w której obrębie przez stulecia kształtowały się i przenikały zjawiska artystyczne, społeczne czy obyczajowe. Zasadne wydaje się więc założenie, że przynajmniej część tych przemian, mód, konwencji znalazła plastyczne odzwierciedlenie na okładkach płytowych.

W tekście tym podejmuję dwa zagadnienia. Po pierwsze, omówiona zostanie rola okładki jako istotnego narzędzia działań marketingowych, a precyzyjniej rozwiązań plastycznych jako elementu strategii budowania przez wytwórnie płytowe korzystnej pozycji na rynku muzycznym. Po drugie, podjęta będzie próba przyjrzenia się w obrębie wydawnictwa płytowego związkom okładek i muzyki. Intuicja podpowiada, że ich zestawienia nie są przypadkowe (lub przynajmniej nie powinny takie być). Spodziewamy się zatem, że projekty graficzne inspirowane są utworami muzycznymi. Wyznaczenie takich zakresów problematyki prowadzi nieuchronnie do podziału tekstu na segment o charakterze analitycznym, ukierunkowany na jedną z funkcji, jaka może być nadana plastycznej oprawie nagrań wydawanych na płytach, oraz zawierający interpretację okładek pod kątem odzwierciedlania struktury, dynamiki bądź innych cech utworów muzycznych. Może to sprawiać wrażenie odrębności partii poświęconych poszczególnym zagadnieniom oraz objęcia refleksją nadmiernie szerokiego pola zjawisk. Do omówienia problematyki okładki płytowej przystępuje się jednak w przeświadczeniu, że dopiero zestawienie kilku perspektyw oglądu pozwala dostrzec jej specyfikę.

Dodać należy, że przedmiotem rozważań nie jest tutaj historia okładki płytowej $^{4}$, lecz jej fenomen jako zjawiska towarzyszącego płycie muzycznej. Stąd

Przyrost udziału winyli w rynku muzycznym wynika bowiem przede wszystkim z drastycznego spadku zainteresowania nabywców nośnikiem cyfrowym przy jednoczesnym niezwykle dynamicznym wzroście popularności platform streamingowych. Prowadzi to między innymi do załamania się dystrybucji CD i do ich wycofywania z oferty sklepów muzycznych. Zob. Best Buy will stop selling CDs as digital music revenue continues to grow, https://www.theverge.com/2018/2/6/16973538/ bestbuy-target-cd-sales-vinyl-cassette (dostęp: 7.08.2021).

3 Zależności między dostępnością muzyki a popularyzacją płyty gramofonowej z jednej, a gwałtownym rozwojem przemysłu fonograficznego z drugiej strony nie wymagają szczegółowego omówienia. Warto natomiast wskazać na znaczenie dla tego procesu wynalezienia taśmy magnetofonowej - a w jeszcze większym stopniu upowszechnienia kasety magnetofonowej (zaprezentowana została przez inżynierów koncernu Philips w 1963 roku). Dzięki nim zaistniała bowiem możliwość łatwego multiplikowania muzyki i jej dystrybuowania w kręgu towarzyskim. Tym samym nieprofesjonaliści zyskali proste $\mathrm{w}$ obsłudze narzędzie do rejestrowania swoich dokonań. $Z$ tej perspektywy mankament niskiej jakości technicznej takich nagrań — zwłaszcza zaś kolejnych powieleń — był niewspółmierny do zalet: głównie wygody i użyteczności.

4 Omówienie w ujęciu historycznym rozwiązań plastycznych towarzyszących muzyce - z podziałem na wydawnictwa nutowe, katalogi, czasopisma, druki ulotne (plakaty, bilety), oprawę róż- 
znaczny stopień uogólnienia formułowanych uwag, w których przywoływanie pojedynczych (choć licznych) realizacji pełni funkcję wyłącznie egzemplifikacyjną. W zdecydowanej większości - jeśli nie wszystkich — wypadków należy je zatem traktować jako jeden z możliwych do wskazania przykładów, wybrany ze względu na jego plastyczną atrakcyjność bądź reprezentatywność omawianych cech. Przy takim podejściu autorstwo poszczególnych okładek nie odgrywa tak istotnej roli jak przy omawianiu na przykład nowatorstwa zastosowanych rozwiązań. Nie będą więc podawane szczegółowe informacje na ten temat (z wyjątkiem uzasadnienia logiką wywodu) $)^{5}$.

Na wstępie warto zauważyć także pewną nieprecyzyjność określenia „okładka płytowa”. W zależności od historycznego i technologicznego kontekstu odnosi się ono bowiem do różnych desygnatów. W epoce dominacji płyt winylowych okładką była wykonana z cienkiej tektury koperta, w którą wsuwało się płytę wraz $\mathrm{z}$ wewnętrznym foliowym opakowaniem ${ }^{6}$. Pełniło ono funkcję dodatkowego zabezpieczenia. Na rewersie okładki umieszczano informacje o wykonawcach oraz tytuły nagrań, często także obszerniejszy tekst wprowadzający. Natomiast awers wypełniała forma plastyczna oraz tytuł płyty i nazwisko głównego wykonawcy. Tak przygotowana okładka pełniła kilka funkcji. Za najważniejsze należy uznać użytkową (z istotnym rozróżnieniem na zabezpieczającą i informacyjną) oraz estetyczną ${ }^{7}$. Ze względu na budowę opakowania oraz trwałość połączenia warstwy plastycznej i tekturowego nośnika okładka była spójną fizycznie całością.

Zmieniło się to wraz z wprowadzeniem płyty kompaktowej. Okładka - jako kilkustronicowa książeczka (z ilustracją na awersie) zawierająca informacje o wykonawcach i prezentowanej muzyce — stała się fizycznie oddzielnym elementem

norodnych nośników nagrań — zob. K. Edge, The Art of Selling Songs: Graphics for the music business, 1690-1990, London 1991. Najważniejsze etapy rozwoju okładki płytowej są obszernie przedstawione w pracy M. Torzeckiego Okładki plytowe. Rzecz o wizualnym uniwersum albumów muzycznych, Poznań 2015; są też istotną częścią rozważań J.M. Łubockiego, Okładka jako część dokumentu na przyktadzie płyty gramofonowej w ujęciu bibliologicznym, Warszawa 2017. Zob. także J. Kurowski, Stynne płyty - stynne okładki, Olsztyn 2017, rozdz. Krótka historia fonografii, s. 9-12.

5 Informacje dotyczące wybitnych projektantów okładek płytowych (między innymi Storm Thorgenson, Roger Dean, Vaughan Olivier, Peter Saville, Reid Miles, Alex Steinweiss) wraz z miniaturami reprodukcji ich najciekawszych prac znaleźć można u M. Torzeckiego, Okładki plytowe, s. 127-181. Warto też sięgnąć do opracowań o charakterze monograficznym: W.J. Burszta, M. Fiderkiewicz, Sferyczne fantazje. W świecie Rogera Deana, Gdańsk 2020; K. Reagan, Alex Stenweiss. The Inventor of the Modern Album Cover, Köln 2011; S. Thorgerson, A. Powell, 100 Best Album Covers, London-New York 1999.

${ }^{6}$ Dotyczy to płyt winylowych, tak zwanych długogrających. Zamiast foliowego opakowania stosowano niekiedy papierową kopertę. Było to rozwiązanie dla użytkownika wygodniejsze, ale głównym jego mankamentem okazała się podatność na rozdarcie, wynikająca z mniejszej odporności mechanicznej. Single wydawano bez tego dodatkowego zabezpieczenia.

7 Wnikliwe omówienie funkcji okładki płytowej zostało przeprowadzone przez J.M. Łubockiego, op. cit.; oraz — ze znacząco odmiennym ich zhierarchizowaniem - M. Torzeckiego, Okładki plytowe. 
uwolnionym od pełnienia funkcji zabezpieczającej. Zadanie ochronne „przejęło” składające się zazwyczaj z trzech części plastikowe opakowanie ${ }^{8}$, wewnątrz którego jest miejsce zarówno na nośnik z nagraniem, jak i okładkę wraz z jej dopełnieniem w postaci wkładki umieszczanej między dwiema częściami opakowania, tworzącymi jego tylną stronę. Dzięki temu, że wkładka obejmuje także krótsze boki pudełka z płytą, po jego zamknięciu całość sprawia wrażenie zespolenia się obu elementów okładki ${ }^{9}$.

Przeprowadzenie wywodu wymaga wskazania konkretnych płyt i okładek. Najdogodniejszą formą byłoby reprodukowanie omawianych rozwiązań plastycznych. Ze względu na uwarunkowania edytorskie oraz konieczność przestrzegania praw autorskich przynależnych twórcom okładek byłoby to w wielu wypadkach utrudnione lub niemożliwe. Dlatego podawane będą informacje - tytuł płyty, wykonawca, wytwórnia oraz rok wydania i numer katalogowy — niezbędne do precyzyjnej identyfikacji przykładów ${ }^{10}$.

\section{Plastyczna identyfikacja wytwórni}

Prezentując nagrania na wysokim poziomie artystycznym i znakomite pod względem technicznym, buduje się markę wytwórni i jej rozpoznawalność. Do zaznaczenia swej obecności na rynku dąży się też między innymi przez stworzenie plastycznego wizerunku firmy. W tym kontekście oprawę plastyczną wydawnictw płytowych można postrzegać jako jeden ze środków służących uzyskaniu przewagi nad konkurencją. Nie bagatelizując znaczenia funkcji ozdobnej projektu okładki, warto więc mu się przyjrzeć jako szczególnemu komunikatowi marketingowemu.

${ }^{8}$ Opis odnosi się do typowego wydania płyty CD. Niektóre nagrania na tym nośniku ukazują się jednak w zwartym, jednoelementowym opakowaniu tekturowym z nadrukiem na stronie tytułowej. $\mathrm{Z}$ tego względu można je niekiedy postrzegać i analizować podobnie jak płyty winylowe.

9 Dla uniknięcia nieporozumień mogących się pojawiać ze względu na różne rodzaje opakowań określenie front/awers używane będzie w odniesieniu do pierwszej strony książeczki okładkowej, natomiast rewers wskazywać na tę część okładki, którą wydobyć można po usunięciu korpusu plastikowego opakowania płyty. Dzięki takiemu przyporządkowaniu znaczeń zachowane zostanie — przynajmniej w zakresie nazewnictwa - pewnego rodzaju powinowactwo między tradycyjnym a współczesnym typem okładki. Możliwe też będzie odnoszenie się do funkcjonalnie tych samych jej elementów niezależnie od ich rzeczywistego usytuowania. Szczegółowe, wieloaspektowe omówienie budowy i funkcji okładki, w tym okładki płytowej, zostało dokonane przez J.M. Łubockiego, op. cit.

10 W przypisach zastosowano zapis nazwisk wykonawców i kompozytorów oraz tytułów w postaci zaczerpniętej z awersu okładek płytowych. Niekiedy uzupełnione zostało niepodane na płycie imię lub rozwinięty jego inicjał. W tekście głównym obowiązywać będzie natomiast zapis zgodny z zasadami przyjętymi dla języka polskiego. Największą dostępną w internecie bazą wydawnictw muzycznych jest portal Discogs.com, na którym odnaleźć można wskazane w tekście okładki. 
W początkowym okresie sprzedaży płyty muzyczne oferowane były w papierowych kopertach, które pozbawione jakichkolwiek nadruków czy w innej formie naniesionych informacji służyły jedynie zabezpieczeniu wrażliwych na uszkodzenie płyt. Dopiero w 1940 roku za sprawą Alexa Steinweissa wytwórnia Columbia zdecydowała się na eksperyment polegający na wykorzystaniu opakowania do celów marketingowych. Nie tylko przez umieszczenie opisu zawartości płyty, lecz także wprowadzenie coraz liczniejszych elementów plastycznych. Wizualna atrakcyjność okazała się doskonałym wabikiem uwagi ewentualnego nabywcy, co potwierdził kilkukrotny wzrost sprzedaży płyt w ,zdobionych” okładkach w stosunku do oferowanych $\mathrm{w}$ dotychczas stosowanych opakowaniach ${ }^{11}$.

Uwidacznia się to między innymi za sprawą serii wydawniczych. Czyż w tym wypadku sednem wizualnej atrakcyjności nie jest bowiem przekaz: jesteśmy renomowaną wytwórnią płytową z bogatym i tak różnorodnym katalogiem nagrań, że możemy przygotować dowolną serię wydawniczą? ${ }^{12}$ Spójność szaty graficznej sprzyja wyeksponowaniu cyklu nagrań w sklepach płytowych, na stronach internetowych, w materiałach promocyjnych. Często odchodzi się przy tym od bezpośrednich konotacji muzycznych. Elementem scalającym może być wówczas - by wskazać propozycje wyróżniające się oryginalnością - na przykład powtarzalny motyw roślinny (seria „Duo Bonsai”" ${ }^{3}$ wytwórni Erato), przestrzenne kompozycje graficzne (seria „3D Classics” ${ }^{14}$ Deutsche Grammophon) bądź ptasie skrzydło (cykl symfonii Antona Brucknera pod dyrekcją Herberta von Karajana ${ }^{15}$ wydanych przez Deutsche Grammophon).

Szczególnie dopracowane plastycznie serie stać się mogą towarem bardziej poszukiwanym przez potencjalnych nabywców. Nie należy więc zbyt pochopnie odrzucić sugestii, że edycja serii płytowej motywowana jest także świadomym wykorzystaniem instynktu kolekcjonera. Wytworzenie u melomanów dążenia do zebrania całości wydawnictwa okazuje się marketingowo udanym pomysłem

11 M. Torzecki, Okladki plytowe, s. 175-181.

$12 \mathrm{~W}$ znacznie mniejszym stopniu dotyczy to serii wydawanych jako kolejne zeszyty przez - zazwyczaj - duże koncerny medialne. Kierowane są one do mniej doświadczonych melomanów, a często stosowanym chwytem marketingowym jest wyrobienie u odbiorcy przeświadczenia, że oferuje mu się wybór najwybitniejszych dzieł w historii muzyki.

13 Na przykład Modest Mussorgsky, Pictures at an Exhibition, Rotterdams Philharmonisch Orkest, James Conlon, Erato 4509-92870-2, 1991.

${ }^{14}$ Franz Schubert, Symphonie No. 9, Chicago Symphony Orchestra, James Levine, Deutsche Grammophon, 3D Classics 429 983-2, 1984; oraz na przykład Ludwig van Beethoven, ,, Hammerklavier-Sonate" Sonate No. 28 op. 101, Daniel Barenboim, Deutsche Grammophon, 3D Classics 429 485-2, 1984.

15 Anton Bruckner, Berliner Philharmoniker, Herbert von Karajan, Symfonien $n r 1$ i 5, Deutsche Grammophon 415 985-2, 1987; Symfonie nr 2, Deutsche Grammophon 415 988-2, 1987; Symfonie $n r$ 3, Deutsche Grammophon 2532 007, 1981; Symfonie $n r$ 4, Deutsche Grammophon 415 277-2, 1985; Symfonie $n r$ 6, Deutsche Grammophon 419 194-2, 1987; Symfonie nr 9, Deutsche Grammophon $2530828,1976$. 
zwłaszcza wtedy, gdy projekt oparty jest na nietypowym i niewątpliwie atrakcyjnym koncepcie ${ }^{16}$.

Strategie wyróżnienia się środkami plastycznymi można — w dużym uproszczeniu - sprowadzić do trzech podstawowych typów, zróżnicowanych pod względem liczby użytych do tego elementów identyfikacyjnych, stopnia ich graficznego doprecyzowania oraz możliwości modyfikacji w obrębie nadrzędnej koncepcji estetycznej. Najprostszym i powszechnie wykorzystywanym rozwiązaniem jest umieszczanie na wszystkich oferowanych przez firmę produktach charakterystycznego logo. Umiejętnie opracowane samo może być — i często $\mathrm{w}$ tej roli bywa stosowane - elementem zdobniczym. Wytwórnią, która od dziesięcioleci z powodzeniem opiera się na eksponowaniu swojego logo, jest Deutsche Grammophon. Znak graficzny poddany został $\mathrm{w}$ tym czasie kilku drobnym przekształceniom, niezmienne jednak pozostało żółte tło, charakterystyczne liternictwo oraz umieszczany ponad napisem wazon z białymi kwiatami, który wydaje się podobny do królewskiej korony. Emblemat zawsze ma kształt prostokąta; w wersji najbardziej rozwiniętej zbliżony jest do ozdobnej tabliczki. Swoista „tarcza herbowa” Deutsche Grammophon nadaje wszystkim firmowanym przez wytwórnię płytom rys wspólnej tożsamości. Ułatwia też identyfikację płyt tej wytwórni, poniekąd zwalniając projektantów okładek z wymogu dążenia do stworzenia, a następnie zachowania plastycznej spójności stylistycznej. Odrębność na rynku muzycznym w stosunku do konkurencyjnych wydawnictw uzyskuje się tutaj za sprawą prostego edytorsko, lecz wśród melomanów powszechnie znanego emblematu ${ }^{17}$.

Skrajnie odmienną strategię uzyskania rozpoznawalności realizuje wytwórnia For Tune. Opracowany projekt, a precyzyjniej — model oprawy plastycznej opiera się na stałym zespole licznych znaków identyfikacyjnych. Charakterystycznym wyróżnikiem jest powielanie awersu okładki na powierzchni płyty i - we fragmencie - na okładce tylnej. Mniej zauważalne, ale równie istotne jest konsekwentne stosowanie kilku drobnych elementów umieszczanych w ściśle określonych miejscach. Są to między innymi: tytuł płyty na prostokątnym jednobarwnym tle (kolor arbitralnie przydzielony jest do różnych odmian gatunkowych muzyki ${ }^{18}$ ), z lewej strony (u dołu) niewielki prostoką — w odpowiedniej

16 Znakomitym przykładem jest wydana w 1991 roku składająca się z 25 płyt seria Deutsche Grammophon MOZART - 3D Collection. Na frontach okładek (niezależnie od informacji o zawartości płyty) znajduje się fragment portretu kompozytora, który można utworzyć po właściwym rozmieszczeniu wszystkich elementów. Na przykład Wolfgang Amadeus Mozart, Symphonien Nos. 40 \& 41 Jupiter, Wiener Philharmoniker, Leonard Bernstein, Deutsche Grammophon 431 267-2, 1991; całość: Deutsche Grammophon 431 267-2- 431 291-2, 1991.

17 Spośród innych wytwórni, których płyty wyróżniają się przez eksponowanie na okładce logo, można wskazać Impulse czy Pablo. O rozpoznawalność zadbały także takie wytwórnie jak Columbia oraz Atlantic, ujednolicając między innymi liternictwo napisów umieszczanych na rantach okładek.

18 Na przykład jazz — magenta; ethno, world, folk — zielony; muzyka dawna — srebrny; muzyka współczesna - pomarańczowy; rock — purpurowy; muzyka klasyczna — turkusowy. 
barwie - przechodzący przez rant i brzeg okładki tylnej i przedniej, piktogram słuchawek w górnej partii płyty. Nazwa wytwórni pisana jest małymi literami; z podziałem na człon biały i czerwony. To jedyne odstępstwo od konsekwentnie stosowanego przez tę wytwórnię płytową liternictwa w kolorze białym. Zwraca uwagę nietypowa lokalizacja zdjęcia artysty - na ostatniej stronie książeczki-okładki, nie zaś na jej stronie tytułowej ${ }^{19}$. Precyzyjnie określony model oprawy plastycznej oparty na prostocie głównych założeń daje tutaj - w zasadzie niezależnie od sposobu wypełnienia schematu i użytych do tego elementów — bardzo spójny efekt estetyczny. $Z$ jednej strony mamy do czynienia ze znaczną redukcją opcji kompozycyjnych, z drugiej jednak — rozszerza się przestrzeń poddawana działaniom plastycznym ${ }^{20}$.

Trudniejszą do zdefiniowania strategię plastycznej odrębności wypracowała wytwórnia Blue Note. Założona w Stanach Zjednoczonych w 1939 roku przez emigrantów z Europy Alfreda Liona i Maxa Margulisa, ukierunkowana była na wydawanie jazzu. Zyskała bardzo duże uznanie za sprawą atrakcyjności oferowanej muzyki. Twórca nadrzędnej idei okładek Blue Note — Reid Miles — określił pewien ikonograficzny i typograficzny wzorzec, który dając dużą swobodę modyfikacji, jednocześnie umożliwiał zachowanie plastycznej spójności projektów ${ }^{21}$ mimo różnorodności rozwiązań szczegółowych. Wynika to nie z powtarzalności lub podobieństwa używanych elementów, lecz przede wszystkim z relacji między nimi. Podstawą koncepcji nie były bowiem stosunkowo łatwe do wyznaczenia kryteria formy, lecz trudniej uchwytne odniesienia estetyczne. Główna rola przypadała inwencji kompozycyjnej, oddziaływaniu proporcjami, nieszablonowo stosowanemu liternictwu. Niesztampowo traktowane było także logo wytwórni22 ${ }^{2}$. Mniej złożony i realizowany z dużą konsekwencją był projekt rewersu okładek (skądinąd bardzo udany pod względem zarówno estetycznym, jak informacyjnym).

19 Zob. wytwórnia For Tune, podstrony z poszczególnymi odmianami muzyki: https://store. for-tune.pl/ (dostęp: 15.12.2020).

20 Przy okazji warto zauważyć, że nośnikiem treści (także plastycznych) od dawna czyniono takie elementy wydawnictw jak naklejki na centrach płyt (label) czy — zwłaszcza po upowszechnieniu się CD - całość ich powierzchni. Warto też dodać, że w epoce technologicznie uboższej wraz z płytą winylową niekiedy nabywało się dopełniające ją materiały. Zwykle były to zdjęcie artystów, plakat, nalepki, a nawet - jak przy płycie Małe WuWu (Małe WuWu, Małe WuWu, Polskie Nagrania Muza SX2650, 1988) — inspirowana treścią piosenek gra planszowa. Ze względu na radykalne zmniejszenie się nośnika zredukowana została wielkość jego opakowania, a co za tym idzie także okładki i wszelkich — ewentualnych — dodatków. Wobec tego standardowej wielkości plakat musiałby więc być wielokrotnie złożony, co oznaczałoby liczne odkształcenia i tym samym w praktyce wykluczałoby jego wykorzystanie.

21 Zob. M. Torzecki, Oktadki ptytowe, s. 169-175.

22 Złożone jest $\mathrm{z}$ nazwy wytwórni i umieszczonej obok plamy barwnej zbliżonej do owalu (niekiedy zaznaczonego jedynie konturem). W niektórych projektach awersów okładek nie pojawia się nawet takie uproszczone logo. 
Wyrazistość plastycznej stylistyki Blue Note w znacznym stopniu określały też umieszczone na większości okładek zdjęcia Francisa Wolffa ${ }^{23}$, które przez dziesięciolecia współtworzyły plastyczną rozpoznawalność wytwórni. Dotyczy to zdecydowanej większości płyt wydanych do lat osiemdziesiątych XX wieku. Późniejsze realizacje nie zachowują konsekwentnie tej linii stylistycznej. Odstępstwa są tak liczne, że dziś powinowactwo z koncepcją Milesa i nieco archaicznym urokiem fotografii Wolffa znacznie się zmniejszyło 24 .

Przykładem szczególnej dbałości o plastyczną spójność okładek jest specjalizująca się w muzyce jazzowej i współczesnej kameralistyce wytwórnia ECM. Wysoka rozpoznawalność płyt tego wydawnictwa uzyskana została dzięki - paradoksalnie - ograniczeniu oprawy plastycznej. Większość okładek stworzono, odwołując się do zaledwie dwóch projektów bazowych. Fronty okładek charakteryzują się - zazwyczaj — pewną surowością. Często głównym elementem jest w pewnym stopniu nieostra fotografia, zwykle monochromatyczna, której tematem czyni się motywy przyrodnicze (z upodobaniem powraca się do z lekka odrealnionych fragmentów krajobrazu). Informacje redukowane są do absolutnie podstawowych i podawane z zastosowaniem bardzo prostego (można by rzec, nieskupiającego uwagi) liternictwa. Do rzadkości należy umieszczenie na froncie okładki wizerunku wykonawcy. Absolutnym wyjątkiem jest okładka ECM z użyciem wielobarwnych kompozycji malarskich czy realistycznie przedstawionych przedmiotów. W innym - jeszcze prostszym, wręcz minimalistycznym — ujęciu ideą zamysłu plastycznego jest zestawienie na awersie okładki jedynie dwóch elementów: tła utrzymanego (najczęściej) w jednym kolorze oraz skontrastowanego z nim pod względem barwy napisu (wykonawca, tytuł płyty, nazwa wytwórni). Takie rozwiązanie w większości realizacji stosowane jest także na rewersie okładki. Z tym że warstwa informacyjna jest bogatsza. Zdarzające się modyfikacje są niewielkie i sporadyczne. Pozornie następuje tutaj redukcja oprawy plastycznej na rzecz funkcji informacyjnej. Mamy jednak przy tym do czynienia z konsekwentnie realizowaną strategią precyzyjnego wyznaczania środkami graficznymi swojej odrębności ${ }^{25}$.

${ }^{23}$ Pasjonat jazzu i fotograf amator. Dołączył do ścisłego kierownictwa wytwórni wkrótce po jej utworzeniu. Większość fotografii Wolffa wykorzystanych na okładkach powstało podczas sesji nagraniowych. Są one osobistym zapisem pracy i atmosfery panującej w studiu, ale też relacji między muzykami.

24 Zob. wytwórnia Blue Note: https://www.bluenote.com/artist/ (dostęp: 15.12.2020); podstrona wortalu Hardformat poświęconego płytom http://www.hardformat.org/designers/reid-miles2/ (dostęp: 28.07.2021); film dokumentalny z 2019 roku w reż. Sophie Huber Blue Note Records: Beyond The Notes; a także G. Marsh, G. Callingham, Blue Note: Album Cover Art, San Francisco 1991; oraz J. Czaja, Blue Note — The Finest in Jazz Since 1939, „Jazzpress” wrzesień-październik 2019.

${ }^{25}$ Zob. wytwórnia ECM, podstrony z dyskografiami muzyków, https://www.ecmrecords.com/ artists (dostęp: 15.12.2020). 
Rozpoznawalność jest też cechą okładek płyt wydawanych przez wytwórnię ACT. Głównym elementem zdobniczym jest — zazwyczaj — kilka kolorowych kresek lub plam barwnych umieszczonych na białym tle. Układają się w bardzo proste kształty, abstrakcyjne w charakterze i minimalistyczne w formie. Ze względu na pozory nieudolności sprawiają wrażenie stylizowanych na rysunki dziecięce. Informacje na froncie okładki o tytule płyty i wykonawcach muzyki podawane są na wszystkich płytach ujednoliconym liternictwem. Na awersach okładek najnowszych nagrań firmowanych przez ACT wprowadzane są coraz śmielej kształty bardziej realistyczne. W katalogu firmy przybywa także projektów z wykorzystaniem fotografii muzyków ${ }^{26}$.

\section{Okładka jako plastyczne odzwierciedlenie muzyki?}

Okładka płytowa, będąc dziełem plastycznym, ma jednak nie tylko walory estetyczne, lecz także użytkowe. Zagadnienia związane z wizualną atrakcyjnością, zmiennością w czasie mód i stylistyk tworzenia okładek, oryginalnością koncepcji projektanta oraz przekazywaniem podstawowych informacji o nagraniu są oczywiste. Pozostaje jeszcze kwestia adekwatności projektu okładki względem muzyki. Wydawać by się mogło, że powinna tutaj zachodzić istotna zbieżność. Nawet wstępne zapoznanie się z choćby niewielką liczbą okładek daje jednak podstawy do wątpliwości. Okazuje się, że powinowactwo plastyki i muzyki często jest powierzchowne.

Zauważa się, że przy mnogości wydawanych płyt projektanci okładek posługują się dość ograniczonym zestawem rozwiązań. Stosunkowo łatwo wskazać podstawowe schematy plastycznej oprawy nagrań. Za główny, czyli najczęściej stosowany, element kompozycyjny należy uznać wizerunek wykonawcy. Zazwyczaj jest to zdjęcie, choć zdarzają się ujęcia $\mathrm{z}$ wykorzystaniem rysunku. W ujęciu nieco bardziej wyrafinowanym sylwetkę artysty/kompozytora uzupełnia instrument, na którym wykonane zostały utwory. Wzbogaca to plastyczną warstwę okładki, a potencjalny nabywca naocznie zyskuje informacje i wyobrażenie, czego może się spodziewać po wydawnictwie. W wypadku muzyki sakralnej częstym motywem jest wykorzystanie symboli religijnych. Na przykład na okładkach płyt z muzyką odwołującą się do chrześcijaństwa często pojawia się krzyż, korona cierniowa, kielich mszalny czy wnętrze świątyni. Warto też zwrócić uwagę na plastyczny wizerunek muzyki operowej. Tu na okładkach pojawić się mogą rekwizyty na-

26 Zob. wytwórnia ACT, https://www.actmusic.com/en/Releases/All-Releases (dostęp: 15.12. 2020). 
wiązujące do realiów teatru muzycznego lub zdjęcia ze spektakli pokazujące wykonawców w charakterystycznych strojach i pozach.

Ze względu na swoisty kod ikonograficzny odrębną grupę tworzą okładki płyt z niektórymi odmianami tak zwanej muzyki popularnej (na przykład rocka progresywnego bądź — choć już w mniejszym stopniu — rapu czy hip-hopu). Jest on szczególnie eksponowany w wywodzących się $\mathrm{z}$ heavy metalu najdynamiczniejszych nurtach muzyki rockowej. Typowy zestaw najbardziej uschematyzowanych przedstawień składa się tu ze szkieletów, czaszek, zwłok, potworów, upiornych postaci lub — w łagodniejszej odsłonie — łańcuchów i zbroczonych krwią mieczy. Ten zestaw elementów kojarzy się często $\mathrm{z}$ demonizmem i ideami satanistyczny$\mathrm{mi}^{27}$. Daleko idąca identyfikacja muzycznej stylistyki z konkretnym typem przedstawień tworzy tak trwały model plastycznych rozwiązań, że utrudnia projektantom nie tylko wprowadzanie nowych elementów, ale także ogranicza swobodę ich przedstawiania w sposób odbiegający od konwencji. W wielu wypadkach mamy więc do czynienia z powtórzeniami, autocytatami, ikonograficzną banalizacją. Stopień schematyzacji wydaje się redukować $\mathrm{w}$ tego rodzaju przedstawieniach warstwę znaczeniową na rzecz wartości subkulturowej spójności przekazu ${ }^{28}$.

Wskazane przykłady są potwierdzeniem tezy o tym, że powinowactwo plastyki i muzyki często ma charakter powierzchowny. Do rzadkości należą bowiem okładki, które byłyby efektem kreatywnego odzwierciedlenia muzyki; a dokładniej - tych jej cech, które projektant uznał za szczególnie ważne lub dające się w przekonujący sposób przekazać środkami plastycznymi. Do wyjątków należy seria wydawnicza Archiv Produktion Galleria Deutsche Grammophon z przełomu lat osiemdziesiątych i dziewięćdziesiątych XX wieku z nagraniami utworów Jana Sebastiana Bacha. Ich okładkowym elementem wspólnym uczyniono zabytkowe zegarki ${ }^{29}$. Przy zestawianiu kompozycji lipskiego kantora i urządzenia mechanicznego kierowano się — być może — kwalifikacją tej muzyki jako opartej na porządku, precyzji, perfekcyjnej pod względem konstrukcji i współdziałania użytych elementów. Równie interesująca interpretacyjnie relacja między okładką a muzyką wytworzona została także przy innym wydaniu kompozycji Bacha.

$27 \mathrm{~W}$ obrębie grupy docelowej funkcjonowanie i odbiór warstwy plastycznej towarzyszącej tej stylistyce muzycznej rządzą się jednak innymi zasadami. Okładkowy sztafaż (niekiedy także powielany podczas koncertów) wydaje się bowiem elementem wizerunku, nie zaś ideowej tożsamości artystów i odbiorców. Zob. K. Ludwicki, O muzyce metalowej, sztuce i okładkach... Z malarzem i grafikiem Arkadiuszem Zajacem rozmawia Konrad Ludwicki, „Studia de Cultura” 2019, nr 3.

${ }_{28}$ Co oczywiście nie wyklucza możliwości ewolucji stylistyki rozwiązań plastycznych. Zob. M. Rychlewski, Rock-kontrkultura - establishment, [w:] Kontrkultura - co nam z tamtych lat?, red. W.J. Burszta, M. Czubaj M. Rychlewski, Warszawa 2005; oraz idem, Rewolucja rocka. Semiotyczne wymiary elektrycznej ekstazy, Gdańsk 2011, podrozdział Okładki, s. 68-73.

29 Johann Sebastian Bach, Englische Suiten, BWV 806-811, Huguette Dreyfus, Deutsche Grammophon - Archiv Produktion Galleria 427 146-6, 1989. 
Tutaj wykorzystano rysunek Leonarda da Vinci, tak zwanego Człowieka witruwiańskiego ${ }^{30}$. Czy matematyczna logika zależności i piękno proporcji budowy ludzkiego ciała mają w tym wypadku odzwierciedlać doskonałości muzyki, której okładka jest wizualnym zwiastunem?

Podobnie metaforyczny przekaz zawarty został w fotografii wykorzystanej na okładce jednej z płyt zespołu Hagen Quartett ${ }^{31}$. Muzycy stoją tu na tle metalowych elementów konstrukcyjnych. W zestawieniu z wykonywanym repertuarem — tak zwana muzyka współczesna - tworzy to spójną całość. Nie dąży się tutaj do przedstawienia słuchaczowi wizualnego ekwiwalentu muzyki. Wskazuje się jednak odniesienia, dzięki którym znajdujące się na płycie utwory zostają umieszczone w konkretnym czasie i kontekście przemian artystycznych. Przywołana środkami plastycznymi awangardowa (niegdyś) idea Miasto - Masa - Maszyna oddawać ma nowoczesność (dziś już nieco „oswojoną”) struktur muzycznych.

Dotychczas wskazane przykłady dotyczyły projektów plastycznych przygotowanych do wydań nagrań już istniejących. Zdarzają się jednak relacje o innym porządku chronologicznym. Na okładce płyty To Whom it May Concern Piotra Wojtasika znajduje się reprodukcja obrazu Eugeniusza Józefowskiego. Tytuł nadany przez malarza - Rhytmic score for the trumpeter Piotr W. - wskazuje na inspirację twórczością trębacza ${ }^{32}$. Wzajemne oddziaływanie wizualności i muzyki bywa ukazywane w sposób nietypowy. Fotograf Guy Le Querrec towarzyszył trzem instrumentalistom $\mathrm{w}$ afrykańskiej wyprawie i w ich subiektywnym odczuciu wykonane wówczas fotografie wpłynęły na kształt tworzonej muzyki. Wspomniano o tym w obszernym opisie płyty Carnet de routes, a na rewersie okładki nazwisko Le Querreca umieszczone zostało wśród muzyków i jako instrument wskazano aparat fotograficzny. Uczyniono tak również na kolejnych dwóch płytach tego instrumentalno-wizualnego kwartetu ${ }^{33}$.

Jako próbę opowieści o muzyce można także traktować współczesne nawiązania do estetyki charakterystycznej dla wydawnictw z muzyką rockową końca lat sześćdziesiątych XX wieku. Projekt do płyty Karma zespołu Hey ${ }^{34}$ jest przywo-

30 Johann Sebastian Bach, Das Wohltemperierte Clavier, Kenneth Gilbert, Archiv Produktion 413439-2, 1984. Motyw ten został wykorzystany także na okładce płyty z muzyką Gustawa Holsta: The Planets, Chicago Symphony Orchestra, James Levine, Deutsche Grammophon 429 730-2, 1990 oraz holenderskiego zespołu Rygar: płyta Modulation z 2012 roku, Space Sound Records SSR-00022.

31 Witold Lutosławski, György Ligeti, Alfred Schnittke, Streichquartette, Hagen Quartett, Deutsche Grammophon 431 686-2, 1991.

32 Piotr Wojtasik, To Whom it May Concern, Indygo 002, 2018.

33 Aldo Romano, Louis Sclavis, Henri Texier, Guy Le Querrec, Carnet de routes, Label Bleu LBLC86569, 1995, Carnet de routes - Suite Africaine, Label Bleu LBLC 6609, 1999, African Flashback, Label Bleu LBLC 6679, 2005.

34 Hey, Karma, Mercury 534 819-2, 1997. Projekt okładki: Marta i Łukasz Dzubalscy. 
łaniem rozwiązań już znanych z wczesnych edycji nagrań między innymi Czesława Niemena ${ }^{35}$, Niebiesko-Czarnych ${ }^{36}$ czy Czerwono-Czarnych $^{37}$. Zastosowanie podobnego liternictwa oraz kolorystyki świadczyć zatem może o dostrzeżonym przez twórców plastycznej oprawy ponadgeneracyjnym powinowactwie artystów. To - ewentualne - podobieństwo twórczości muzycznych zostało wyrażone bez odnoszenia się bezpośrednio do muzyki. Nastąpiło jej „odsunięcie” do interpretacyjnego tła ${ }^{38}$, a korespondencję między okładkami przeprowadzono w obrębie środków, odniesień i skojarzeń plastycznych ${ }^{39}$.

W najbardziej udanych projektach okładek płytowych możemy zaobserwować — oprócz znakomitego warsztatu - elementy gry w skojarzenia i modyfikacje prowadzonej z odbiorcą i z innymi artystami. Rozgrywka ta polega na odświeżeniu starych lub stworzeniu nowych relacji i w niewielkim stopniu przebiega $\mathrm{w}$ odniesieniu do muzyki. Głównym jej polem jest bowiem rzeczywistość plastyczna. Nawet jeśli zdarza się projektantom okładek nawiązywać do muzyki, to jednak prowadzi ich przy tym wyobraźnia ukształtowana przede wszystkim przez dzieła malarskie. Pozostają więc de facto w obrębie sztuk plastycznych. Stąd tak wiele na okładkach płyt motywów, cytatów, nawiązań lub nawet dosłownych zapożyczeń z dorobku malarstwa. Pojawia się też obraz jako przedmiot, wokół którego nadbudowywana jest idea okładki. Do tego celu wykorzystano na przykład portrety Mozarta ${ }^{40}$.

35 Czesław Niemen, Sukces, Polskie Nagrania Muza XL 0390, 1968. Projekt okładki: Czesław Niemen (zdjęcie: Władysław Pawelec).

36 Niebiesko-Czarni, Mamy dla was kwiaty, Pronit XL 0481, 1968. Projekt okładki: Waldemar Świerzy.

37 Czerwono-Czarni, 17000 000, Polskie Nagrania Muza XL 0458, 1968. Projekt okładki: Helena Matuszewska.

38 Mamy tutaj do czynienia z dwustopniowymi odniesieniami. Wskazane w tej części wywodu okładki towarzyszą wprawdzie nagraniom polskich wykonawców, jednak rzeczywistym punktem plastycznych odwołań, zarówno projektów z lat siedemdziesiątych XX wieku, jak i bardziej nam współczesnych, jest dla nich estetyka epoki Flower Power z jej kolorystyczną krzykliwością. Zob. K. Rynkowska, Ach, kontrkultura, czyli o okładkach ptyt lat 60. i 70. słów kilka, https://kulturalnemedia.pl/muzyka/kontrkultura-o-okladkach-plyt-60-i-70-slow-kilka/ (dostęp: 7.05.2021).

39 O wykorzystywaniu już sprawdzonych rozwiązań przy tworzeniu okładek obszernie pisze Mateusz Torzecki. Dla oddania następujących w tym obszarze zapożyczeń i przetworzeń posługuje się między innymi określeniem „,autorepetycja”. Neologizm ten odnosić się ma do nawiązań czynionych przez plastyków do własnych projektów. Tymczasem jest to zjawisko dotyczące nie tylko „powtórzeń" autorskich. Projekt wyróżniający się oryginalnością bądź w świadomości odbiorców ściśle powiązany z wybitną płytą staje się w obrębie grupy osób zainteresowanych tą odmianą muzyki powszechnie rozpoznawalny. Zaczyna więc być swoistym punktem odniesienia do następnych propozycji plastycznych. Termin zaproponowany przez Torzeckiego trafnie wskazuje zatem na istotny aspekt przygotowywania i recepcji okładek, czyli trwałość zachodzących w tej przestrzeni relacji z konwencjami plastycznymi i tradycją malarstwa. Zob. M. Torzecki, Oktadki płytowe, rozdz. 2. Repetycja i jej rola w powstaniu kanonu okladek plytowych, s. 93-123.

40 Wolfgang Amadeus Mozart, Frühe Symphonien, Wiener Philharmoniker, James Levine, Deutsche Grammophon 431 711-2, 1991. Ten sam portret wykorzystany został w 1991 roku na 
Ważkim argumentem świadczącym o dominacji wewnątrzplastycznych odniesień okładek płytowych jest obecność graficznych znaków kulturowych. Jako przykład można wskazać okładkę do płyty Kolaboracja II zespołu Dezerter. Widniejący na niej sztandar z portretami trzech ideologów ruchu komunistycznego był niegdyś jednym z najczęściej pojawiających się emblematów podczas uroczystości firmowanych przez ugrupowania socjalistyczne. Dziś jednak jego wydźwięk ma znaczenie li tylko historyczne. W wersji przygotowanej na okładkę głowy Marksa, Engelsa i Lenina zostały zastąpione twarzami przywódców grupy rockowej $^{41}$. Przetworzenie jest atrakcyjne plastycznie i nośne interpretacyjnie, okładka zaś w tej postaci jest też znakiem czasu, gdyż jej publikacja w 1989 roku świadczy o skali zachodzących wówczas w Polsce zmian politycznych.

Przy wydaniach nagrań z tak zwaną muzyką poważną bardzo często na okładkach umieszcza się reprodukcje wedut, pejzaży, portretów czy scen rodzajowych. Liczne są przy tym nawiązania do stylu malarstwa charakterystycznego dla epoki, z której pochodzi dzieło muzyczne. Chętnie sięga się do secesji ${ }^{42}$ czy impresjonizmu ${ }^{43}$. Wyraźne są odwołania do dzieł najznamienitszych twórców: Marca Chagalla (Daphnis et Chloé Ravela ${ }^{44}$ ), Gustava Klimta (między innymi cykl płyt z symfoniami Beethovena w wykonaniu Wiener Philharmoniker pod dyrekcją Claudia Abbado oraz Romeo \& Juliet Prokofiewa ${ }^{45}$ ), Henriego de Toulouse-Lautreca (wydane w 1998 roku na jednej płycie utwory Offenbacha, Gounoda, Chabriera i Thomasa ${ }^{46}$ ) itp. Można też natrafić na inspiracje Fridą Kahlo ${ }^{47}$, René Magritte' $\mathrm{em}^{48}$ czy Henrim Julienem Rousseau, zwanym Celnikiem ${ }^{49}$.

kilku okładkach płyt z utworami Mozarta: Die Sonaten für Klavier und Violine, Deutsche Grammophon 431 784-2; Die Frühen Strreichquartette, Hagen Quartett, Deutsche Grammophon 431 645-2; Die Bläserkoncerte, Orpheus Chamber Orchestra, Deutsche Grammophon 431 665-2 itp.

41 Dezerter, Kolaboracja II, PolJazz PSJ-211, 1989. Projekt okładki: Piotr Tofil.

42 Hector Berlioz, Melodies Songs Lieder, Deutsche Grammophon 435 860-2, 1994.

43 Claude Debussy, Preludes, Deutsche Grammophon 427 391-2, 1988.

44 Maurice Ravel, Daphnis et Chloé, Deutsche Grammophon 427 679-2, 1989.

${ }^{45}$ Ludwig van Beethoven, Wiener Philharmoniker, Claudio Abbado - Symfonien Nos. 1 \& 4, Deutsche Grammophon 427 301-2, 1989; Symfonie Nos. 2 \& 5, Deutsche Grammophon 423 590-2, 1987; Symfonie No. 3 »Eroica«, Deutsche Grammophon 419 597-2, 1987; Symfonie No. 6 »Pastorale«, Deutsche Grammophon 419 779-2, 1987; Symfonien Nos. 7 \& 8, Deutsche Grammophon 423 364-2, 1987; Symfonie No. 9, Deutsche Grammophon 419 598-2, 1987; oraz na przykład Sergei Prokofiev, Romeo \& Juliet (Excerpts), Berliner Philharmoniker, Esa-Pekka Salonen, Sony Classical SK 42 662, 1992.

46 Jacques Offenbach: Gaité Parisienne, Charles Gounod: Faust - Ballet Music, Emmanuel Chabrier: España, Ambroise Thomas: Mignon, Deutsche Grammophon 423 698-2, 1988.

47 Kora, kora ola, ola!, Polskie Radio PRCD 349, 2003.

48 Pink Floyd, Wish You Were Here, Harvest SHVL 814, 1975.

49 Maryla Rodowicz, Jest cudnie, Sony BMG Music Entertainment 88697435212, 2008. 
Również współcześni artyści (jak Wilhelm Sasnal, Wojciech Siudmak, Zbigniew Libera ${ }^{50}$ ) nie odżegnują się od współpracy z przemysłem muzycznym. Wielokrotnie na potrzeby wydawnictw fonograficznych wykorzystywane były też obrazy Zbigniewa Beksińskiego (choćby płyta Moonshine zespołu Collage ${ }^{51}$ ). Oprawami plastycznymi do płyt parał się też Andy Warhol. Najbardziej znana okładka jego autorstwa powstała do płyty The Velvet Underground \& Nico ${ }^{52}$. Opracował też kilka okładek dla wytwórni Blue Note.

Niekiedy nadaje się warstwie plastycznej okładki rolę bez mała narracyjną. Projektanci oprawy nagrań trzeciej symfonii Ludwiga van Beethovena często wprowadzają elementy bezpośrednio odwołujące się do Napoleona ${ }^{53}$. Pierwotnie dzieło miało być jemu poświęcone, lecz kompozytor oburzony ogłoszeniem się przez niego cesarzem Francuzów dedykację wycofał. Mamy zatem do czynienia z odniesieniem właśnie do tego wydarzenia i okoliczności powstania muzyki, nie zaś do jej charakteru, struktury czy choćby dynamiki. Zatem źródłem inspiracji nie jest tutaj muzyczność, lecz historia muzyki. Ten epizod najdobitniej oddaje okładka, na której widzimy Beethovena obalającego kopniakiem portret Napoleona ${ }^{54}$.

Charakter tworzonej okładki często w znaczącym stopniu określa przekaz zawarty w tekstach umieszczonych na płycie piosenek. Pisze o tym Dagny Kurdwanowska w biografii Tori Amos, wokalistki, pianistki i autorki piosenek. $\mathrm{Na}$ okładce płyty Little Earthquakes ${ }^{55}$ z 1991 roku

Amos w niebieskich ogrodniczkach przytrzymuje się krawędzi drewnianej skrzyni, w której przykucnęła przy malutkim fortepianie. Nie do końca wiadomo, czy próbuje się z niej wydostać, czy pudło raczej jest jej schronieniem. Przeskalowany obraz był zainspirowany powieścią Alicja w Krainie Czarów Lewisa Carrolla. Był piękną metaforą dla tego, co kryło się na płycie — dla opowieści o tym, co ogranicza, o przełamywaniu strachu, o przekraczaniu własnych słabości i wykrzykiwaniu swojego protestu ${ }^{56}$.

Obraz umieszczony na okładce jest ekwiwalentem treści przekazywanych w piosenkach; komentarzem, ale też ich plastycznym rozwinięciem. Prowadzi to

50 F. Lech, Oceniaj ptytę po oktadce: przygody fonograficzne polskich artystów, https://culture.pl/ pl/artykul/oceniaj-plyte-po-okladce-przygody-fonograficzne-polskich-artystow (dostęp: 7.05.2021). Rozmowy z polskimi twórcami okładek płytowych zob. M. Torzecki, Polska okładka płytowa, Poznań 2017.

51 Collage, Moonshine, Metal Mind Records MMPCD0021, 1994.

52 The Velvet Underground \& Nico, The Velvet Underground \& Nico, Verve Records V-5008, 1967.

53 Zob. https://www.discogs.com/search/?limit=100\&q=eroica\&type=all\&genre_exact=Classi cal\&page $=1$ (dostęp: 18.01.2021).

${ }^{54}$ Ludwig van Beethoven, Franz Liszt, Symphonie Nr. 3 Eroica, Cyprien Katsaris, Teldec $6.43201 \mathrm{AZ}, 1985$.

55 Tori Amos, Little Earthquakes, EastWest 7567-82358-2, 1991. Projekt okładki: Cindy Palmano, Alan Reini.

56 D. Kurdwanowska, Tori Amos, Czerwonak 2014, s. 129. 
niekiedy do edycji płyty z kilkoma - dystrybuowanymi równocześnie - wersjami okładek. Przykładem — wydana dekadę później płyta Amos Strange Little Girls. Artystka wciela się tutaj w czternaście wykreowanych w napisanych przez siebie tekstach kobiet o odmiennych charakterach, pochodzeniu i doświadczeniach życiowych. Różnorodność bohaterek została oddana stylizacjami wokalistki na kilka z nich i ukazana na fotografiach wykorzystanych przy stworzeniu sześciu wersji okładki towarzyszącej płycie ${ }^{57}$. Dzięki literackim inspiracjom powstała zatem idea projektu plastycznego spójnego z przesłaniem płyty, choć — jak w wielu innych wskazanych wypadkach — pozbawionego związków z warstwą muzyczną.

Podobnie bywa przy tworzeniu plastycznej oprawy utworów instrumentalnych opatrzonych jednoznacznym tytułem. Za przykład niech posłużą okładki płyt z nagraniami kompozycji Antonia Vivaldiego Le Quattro Stagioni. „Pierwszym wyborem" jest odniesienie się w projekcie plastycznym do dynamiki przyrody, ukazanie różnorodności aury. Częste rozwiązanie polega na umieszczeniu obok siebie czterech zróżnicowanych odsłon tego samego pejzażu, co w zamyśle twórcy okładki ma odzwierciedlać pory roku ${ }^{58}$. Koncept skądinąd uzasadniony programowością dzieła muzycznego zyskuje na atrakcyjności po uwolnieniu się od pokusy dosłowności. Wtedy cykliczność pór roku uwidoczniona jest na przykład $\mathrm{w}$ obrębie korony jednego drzewa $\mathrm{w}$ różnych fazach rocznego rozwoju ${ }^{59}$ albo owocu jabłoni od kwitnienia, przez dojrzewanie, aż do pozostałości w postaci ogryzka $^{60}$. Trafnie, z polotem użyta metafora sprawia, że okładka zdaje się odnosić nie tylko do muzyki. Jakkolwiek tytuł utworu i użyte przez kompozytora środki wyrazu w znacznej mierze mogą wpływać na projekty plastyków, to nawet do dzieł tak sugestywnych jak Cztery pory roku powstawały okładki całkowicie wolne od ,presji” muzyki. Mamy więc także w tym wypadku rozwiązania, w których

57 Tori Amos, Strange Little Girls, Atlantic 7567-83486-2, 2001. Projekty okładek: Blue Source, fotografie autorstwa Thomasa Schenka. Ponadto w obrębie każdej z wersji okładki niekiedy wprowadzane są drobne modyfikacje w sposobie ukazania głównej postaci. Są to zmiany w kolorystyce, kadrowaniu czy dodatkowych napisach. W kilku oficjalnych okładkowych odsłonach ukazał się także album Led Zeppelin In Through the Out Door, Swan Song SSK 59410, 1979. Interesujące są przetworzenia głównego motywu na okładce płyty zespołu Pink Floyd Ummagumma, Harvest SHDW 1/2, 1969. Pisze o nich M. Torzecki przy okazji kreślenia twórczej sylwetki wybitnego projektanta okładek Storma Thorgersona, zob. M. Torzecki, Okładki płytowe, s. 132-147.

58 Antonio Vivaldi, Le Quattro Stagioni, Roberto Michelucci, I Musici, Philips 6500 017, 1972.

59 Antonio Vivaldi, Le Quattro Stagioni, Gidon Kremer, London Symphony Orchestra, Claudio Abbado, Deutsche Grammophon 413 726-2, 1981.

60 Antonio Vivaldi, Le Quattro Stagioni, Michel Schwalbé, Berliner Philharmoniker, Herbert von Karajan, Deutsche Grammophon 415 301-2, 1985. Podobnie uczyniono z krzakiem róży, przedstawiając jego wygląd od wiosennych gałązek po przywiędłe liście pokryte szronem: Antonio Vivaldi, Le Quattro Stagioni, Wolfgang Schneiderhan, Festival Strings di Lucerne, Rudolf Baumgartner, Deutsche Grammophon 2535 105, 1977. 
wykorzystano typowe elementy: portret wykonawcy (indywidualnie ${ }^{61}$ i z instrumentem $^{62}$ ), instrument ${ }^{63}$, scena rodzajowa ${ }^{64}$, weduta ${ }^{65}$, kompozycja plastyczna ${ }^{66}$.

Powtarzanie tych samych lub zbliżonych motywów może prowadzić do uformowania się ikonograficznego kanonu, który bywa utożsamiany z plastyczną manifestacją określonej odmiany muzyki. W efekcie powstawać by miała okładka „gatunkowa" o stałych konotacjach muzycznych. Podejmowane na tej podstawie klasyfikacje oparte są jednak na bardzo mylących przesłankach interpretowanych w przeświadczeniu o znacznej i konsekwentnie obowiązującej konwencjonalizacji rozwiązań plastycznych. Tymczasem nawet w death i black metalu, czyli gatunkach bodaj najbardziej ujednoliconych pod względem graficznego komunikatu, wskazać można liczne wyjątki. Nie ma zatem w pełni przekonujących podstaw do uzasadnienia tezy o ścisłym powiązaniu oprawy plastycznej płyt z podziałami gatunkowymi w obrębie muzyki ${ }^{67}$.

Gros okładek pod względem gatunkowych informacji charakteryzuje się znaczną ,przezroczystością", to znaczy na ich podstawie trudno z dużą trafnością kwalifikować płytę do odpowiedniej stylistyki muzycznej. Zdarza się wprawdzie, że na przykład wizerunek wykonawcy skłania do takich decyzji, są to jednak przyporządkowania opierające się na image'u artysty. Tymczasem podstawowym zagadnieniem jest sposób wypełnienia powierzchni okładki, użyte do tego środki plastyczne - nie zaś wygląd uchwyconych na fotografii postaci ${ }^{68}$. Trzeba przy tym pamiętać, że wskazane podstawowe rozwiązania, motywy, schematy ikonograficzne z porównywalną intensywnością występują na okładkach płyt z wszystkimi odmianami muzyki.

Można natomiast mówić o odmienności w ich prezentacji pod kątem choćby ekspresji bądź kolorystycznej odwagi. Prawdą jest bowiem, że okładki płyt z nagraniami tak zwanej muzyki poważnej — w porównaniu do wydawnictw rocko-

61 Antonio Vivaldi, Le Quattro Stagioni, Anne-Sophie Mutter, Deutsche Grammophon 463 259-2, 1999.

62 Antonio Vivaldi, Le Quattro Stagioni, Viktoria Mullova, Chamber Orchestra of Europe, Claudio Abbado, Philips 420 216-1, 1987.

63 Antonio Vivaldi, Le Quattro Stagioni, Salvatore Accardo, I Solisti Delle Settimane Musicali Internazionali di Napoli, Philips Digital Classics 422 065-2, 1989.

64 Antonio Vivaldi, Le Quattro Stagioni, Iona Brown, Academy of St. Martin-in-the-Fields, Philips $9500717,1980$.

65 Antonio Vivaldi, Le Quattro Stagioni, Felix Ayo, Kammerorchester Berlin, Vittorio Negri, ETERNA $826857,1981$.

${ }^{66}$ Antonio Vivaldi, Le Quattro Stagioni, Frequenz 045-004, 1989.

67 Zob. D. Brackett, Categorizing Sound: Genre and Twentieth-Century Popular Music, Oakland 2016. Autor omawia historię tworzenia się i ewoluowania kategorii gatunków muzycznych, odwołując się do realiów branży fonograficznej w Stanach Zjednoczonych.

${ }^{68} \mathrm{Z}$ podobnym interpretacyjnym dystansem należy podchodzić do innych elementów kompozycyjnych okładki. Niezależnie od rodzaju przywołanego na niej motywu nie tworzy on bowiem w zdecydowanej większości realizacji — istotnej podstawy do podejmowania rozstrzygnięć (w tym także gatunkowych) dotyczących muzycznej zawartości płyty. 
wych - cechuje większa estetyczna zachowawczość. Pewne przesłanki pomocne w takiej niezobowiązującej klasyfikacji można by więc wywieść na podstawie analizy sposobu ukazania danego motywu i użytych do tego środków. Nawet jednak wtedy - zważywszy na uniwersalność motywów - kierując się stylistycznymi odmiennościami plastycznego opracowania, uzyskiwalibyśmy co najwyżej domniemanie gatunkowo-muzyczne. Większe prawdopodobieństwo precyzji w tym zakresie wynikałoby nie tyle z rozpoznania cech pojedynczej okładki, ile znajomości graficznej konwencji przyjętej przez wytwórnie płytowe. Dzięki temu nieco odrealnione czarno-białe zdjęcie pejzażu bylibyśmy skłonni uznać za spełniające kryteria estetyczne ECM; nie rozstrzygałoby to jednak przynależności tak zilustrowanej płyty do firmowanych przez to wydawnictwo nurtu jazzowego bądź określanego jako „New Series” (kameralistyka zorientowana na współczesną muzykę poważną $)^{69}$.

\section{Uniwersalność okładki płytowej}

„Nie wolno zapomnieć, że okładce zawsze towarzyszy muzyka, a co za tym idzie nie można analizować elementu graficznego bez uwzględnienia rodzaju nagrań zawartych na płycie"70 — pisze Iwetta Sobczyk, omawiając książkę Mateusza Torzeckiego. Można by się z tym zgodzić, ale wyłącznie przy założeniu, że okładka jest tworzona, by muzyce nie tyle towarzyszyć, ile być wobec niej dopowiedzeniem, komentarzem czy polemiką. Tymczasem interpretacja materiału faktograficznego prowadzi nieuchronnie do wniosku, że warunek ten spełniany jest sporadycznie. Trudno bowiem w przekonujący sposób wykazać istnienie interpretacyjnie istotnego związku między oferowaną na płytach muzyką a towarzyszącymi jej typowymi projektami plastycznymi. Bardzo dużą grupę tworzą okładki zaprojektowane bez jakiegokolwiek powinowactwa z warstwą muzyczną. Zazwyczaj ilustracja przedstawia pejzaż, scenę rodzajową, kompozycję graficzną czy umieszczony na jednolitym tle kwiatostan. Muzyka i jej cechy są wtedy całkowicie pomijane. Podobnie jest z okładkami, na których wykorzystuje się motyw instrumentu bądź wizerunek wykonawcy czy kompozytora. Jest to rozwiązanie bodaj najczęściej stosowane i łatwe do uzasadnienia, gdyż odwołujące się do

69 Mimo to rozpowszechniona jest skłonność do łączenia plastycznego opracowania okładki z konkretnymi odmianami muzyki. Jeśliby nawet zgodzić się z takim podejściem i interpretacją warstwy graficznej, trzeba to zrobić z koniecznym zastrzeżeniem, iż dotyczy to co najwyżej podstawowej kwalifikacji do zbioru tak zwanej muzyki poważnej bądź popularnej. Odrębną grupę przy takich decyzjach tworzą płyty z muzyką ludową, gdyż na ich okładkach bardzo często umieszczane są — zazwyczaj rozstrzygające wszelkie wątpliwości - elementy rustykalne.

70 I. Sobczyk, Mateusz Torzecki, Okładki płyt. Rzecz o wizualnym uniwersum albumów muzycznych, Instytut Kultury Popularnej, Poznań 2015, „Audiosfera. Koncepcje — Badania — Praktyki” 2016, nr 2, s. 106. 
najprostszych skojarzeń. Umieszczone na okładce zdjęcie artysty odzwierciedla jednak wykonywaną przez niego muzykę z podobną precyzją, jak zdjęcia pisarza oddaje charakter jego powieści. Co najwyżej odbiorca uzyskuje złudzenie nieco bardziej osobistej relacji z twórcą. W minimalnym stopniu nawiązania do muzyki znajdują się w projektach wskazujących na etniczną lub kulturową odmienność nagrań. Ewidentne jest tutaj dążenie do treściowego wzmocnienia środkami plastycznymi - także przez okładkę pełnionej — funkcji informacyjnej.

Warto odwołać się jeszcze do ciekawego zjawiska, choć rozwijającego się na obrzeżach fonograficznej rzeczywistości, jakim są konkursy okładek płytowych i wystawy najlepszych projektów. To okazja do zastanowienia się, jakimi kryteriami winniśmy się kierować przy ocenie tych prac; a szerzej — czym jest okładka płytowa, jak ją sytuować w przestrzeni sztuki i w jakiej roli — oprócz użytkowej i informacyjnej — może być wykorzystywana. Jeśli bylibyśmy skłonni uznać projekt plastyczny okładki za związany z muzyką, z którą jest oferowany, to zasadne wydaje się założenie konieczności rozpatrywania go przede wszystkim w obrębie tej relacji. Obrady jury musiałyby być zatem podporządkowane dążeniu do zobaczenia/wysłyszenia drogi, którą przemierzył projektant okładki w dążeniu do oddania środkami plastycznymi specyfiki utworu muzycznego. Dla zwolenników takiego podejścia okładka jest — lub powinna być — plastyczną emanacją muzyki. Oderwanie od warstwy audio pozbawiałoby okładkę najważniejszego kontekstu jej istnienia. Tego rodzaju autonomizacja byłaby po części równoznaczna z jej redukcją do waloryzowanego estetycznie opakowania. Czyniłoby to z niej wówczas „obrazopodobną” wypowiedź plastyczną o trudnej do zdefiniowania tożsamości.

Odrębnym zagadnieniem - ledwie zarysowanym — jest rola okładki jako narzędzia promocji wytwórni płytowej, współtworzenia i umacniania jej pozycji na rynku fonograficznym. Konsekwentnie stosowany spójny i atrakcyjny projekt graficzny jest ważnym elementem strategii zaznaczania przez firmę swojej odrębności, a zarazem uzyskania wśród melomanów wysokiego poziomu rozpoznawalności. Powodzenie w tym zakresie przekłada się na wymierne korzyści finansowe. W wymiarze zarówno artystycznym, jak i marketingowym można analizować także ilość i różnorodność oferowanych przez wydawnictwo serii płytowych. Nadawana im jednorodna szata graficzna pozwala na wyodrębnienie tych nagrań spośród innych propozycji płytowych. Również tutaj projektanci okładek płytowych wydają się poszukiwać inspiracji poza muzyką ${ }^{71}$.

Nie umniejsza to artystycznej wartości ich prac. Niejednokrotnie prowadzi jednak do sytuacji, w której błędem okazuje się oczekiwanie po okładce wzajemnej

71 Wynika to nie tylko z analizy okładek, lecz także z wypowiedzi plastyków. Na przykład wybitnego grafika Rosława Szaybo, który przedstawia okoliczności powstania ikonicznej okładki do płyty British Steel zespołu Judast Priest, CBS S CBS 84160, 1980: Z pewnościa jestem zawodowcem - wywiad z Rosławem Szaybo, https://culture.pl/pl/artykul/z-pewnoscia-jestem-zawodowcem-wywiad-z-roslawem-szaybo (dostęp: 8.05.2021). 
odpowiedniości muzyki i obrazu bądź wizualnego ekwiwalentu cech konkretnego utworu muzycznego. Jeśli nie ma intencji odzwierciedlenia muzyki środkami plastycznymi, wówczas może to prowadzić do ich arbitralnego zestawienia. Często plastycznie atrakcyjnego, lecz nabudowanego wokół tytułu kompozycji lub płyty, dyktowanego tekstami piosenek bądź okolicznościami powstania muzyki; bez dbałości o interpretacyjną osmozę na styku dźwięku i obrazu. Dobór okładek nie jest wprawdzie przypadkowy, lecz bez trudu możemy wyobrazić sobie prawie dowolną ich zamianę. Bardzo często - dotyczy to nie tylko projektów wykorzystujących krajobraz, grafikę, motywy roślinne czy nawet portret wykonawcy - wybór konkretnego przedstawienia w niewielkim stopniu determinowany jest rodzajem nagrania. Na licznych przykładach można więc dowieść, że plastyczną oprawę wprowadza się w roli „okładki uniwersalnej” — pozbawionej czytelnych powiązań z muzyką.

Jednak udostępniana przez artystów i wytwórnie muzyka wydaje się dość mocno sprzęgnięta z obrazem. Można o tym się przekonać podczas korzystania z różnych platform streamingowych. Odsłuchiwanej muzyce często towarzyszy jakiś rodzaj plastycznej animacji z wykorzystaniem na przykład grafiki, zdjęć wykonawcy bądź uproszczonego widma graficznego, ale także dowolnych motywów i elementów pozostających bez związku z muzyką: znów mogą się pojawić krajobrazy, kwiaty, widoki miast itp. Natomiast przy indeksie nagrań umieszczana jest miniatura okładki. Wymogi techniczne powodują jednak, że w mniejszej rozdzielczości zacierają się jej szczegóły ${ }^{72}$. Ilustracja z konieczności podlega plastycznemu uproszczeniu; także na etapie projektowania, gdy uwzględniane są możliwości już nie tylko poligraficzne, lecz także edycyjne portalu internetowego. „Okładka dzisiaj to skrót myślowy, skojarzenie pośrednie lub bezpośrednie. Znak na drodze. Musisz go zauważyć, a nie zastanawiać się, co robi i co oznacza" ${ }^{\text {"73 }}$. Często obraz zostaje już na etapie projektowania świadomie zredukowany do piktogramu uwolnionego od znaczeniowych powinowactw z muzyką. Jego zadanie w wielu wypadkach polega jedynie na tym, by muzyce towarzyszyć i ułatwić dzięki temu odbiorcy identyfikację konkretnego nagrania lub poszukiwanej płyty.

Istotne są też możliwości techniczne urządzeń, dzięki którym mamy kontakt z muzyką. Jak zauważa M. Rychlewski:

Odtwarzacze plików MP3 eliminują całkowicie wizualny aspekt komunikatu rockowego, redukując wielokodowy przekaz do dwóch kodów: muzycznego i tekstowego. Okładki, ciągle stanowiące nieodłączny element singli czy płyt długogrających, nie dają się tutaj w żaden sposób

72 Zyskuje się jednak nieporównanie większe możliwości uatrakcyjnienia plastycznej oprawy nagrań, polegające choćby na przetworzeniu dwuwymiarowości właściwej tradycyjnym okładkom płytowym. Tego typu rozwiązania nie są jednak tutaj przedmiotem zainteresowania, wykraczają bowiem poza zakres przyjętej definicji okładki.

73 Oktadka jest jak znak drogowy. Rozmowa z jury konkursu 30/30, http://freshmag.pl/maga zyn/lifestyle/3030-wywiad-85 (dostęp: 28.07.2021). 
reprodukować, w związku z czym słuchacz może w ogóle nie mieć o nich żadnego wyobrażenia. Rozbiciu ulega zatem nienaruszalna (zdawałoby się) semiotyczna triada dźwięku, słowa i obrazu, skupiona w podstawie jednego nośnika-przedmiotu ${ }^{74}$.

Wprawdzie takie rozumowanie zawiera kilka podstawowych błędów (nagraniu skompresowanemu do formatu MP3 może towarzyszyć element graficzny, a wiele urządzeń umożliwia jednoczesne odtworzenie treści dźwiękowej i wizualnej), to jednak zawarta w nim kasandryczna w wymowie ocena nie jest całkowicie pozbawiona słuszności.

Nie zmienia to jednak faktu, że - nawet w tej ograniczonej formie - często nadal mamy do czynienia z plastycznym opakowaniem utworów muzycznych. Trudno się temu dziwić, skoro od kilkudziesięciu lat przy kolejnych edycjach płyt łączono muzykę z obrazem. Wpłynęło to więc na naszą — nabywców nagrań - wyobraźnię i utrwaliło się w oczekiwaniach. A przecież wiemy, że muzyka bez plastycznej otuliny istnieje równie doskonale. Być może nawet lepiej, pełniej, gdy[ż] bodźce wzrokowe nie odciągają uwagi od napływających dźwięków.

\section{A record jacket or music jacketed in visual art}

Abstract

A record cover can be described and analyzed, to some extent independently, on three levels: as an item of packaging, a source of information and an object of artistic value. The presented order reflects the way its perception has been evolving over time. Without losing its practical function, an album cover has become the subject of aesthetic appraisal. We take a closer look at the role of a cover design in gaining brand recognition by a record company on the phonographic market. To this end, record labels can use an outstanding logo (Deutsche Grammophon), a characteristic pattern (For Tune) or a general decorative concept (Blue Note). Releasing series of records devoted to individual players/composers, musical styles or forms in uniformly designed covers is yet another way of establishing and promoting a label. Another important issue discussed here is the correspondence between music and the record covers accompanying it. Intuition would suggest some sort of affinity between the two or a record cover being a complementary addition to the musical content. In many cases, however, any such connections are hard to find. What we will see more often is a random nature of a body of music and a record cover juxtaposition.

Keywords: cover, record, record label, marketing, music

74 M. Rychlewski, Historia rocka wedtug nośników, „Kultura Współczesna” 2009, nr 3, s. 149. 


\section{Bibliografia}

Brackett D., Categorizing Sound: Genre and Twentieth-Century Popular Music, Oakland 2016. Burszta W.J., Fiderkiewicz M., Sferyczne fantazje. W świecie Rogera Deana, Gdańsk 2020.

Czaja J., Blue Note — The Finest in Jazz Since 1939, „Jazzpress” wrzesień-październik 2019. Edge K., The Art of Selling Songs: Graphics for the music business, 1690-1990, London 1991.

Kurdwanowska D., Tori Amos, Czerwonak 2014.

Kurowski J., Stynne plyty - stynne okładki, Olsztyn 2017.

Ludwicki K., O muzyce metalowej, sztuce i okładkach... Z malarzem i grafikiem Arkadiuszem Zajacem rozmawia Konrad Ludwicki, „Studia de Cultura” 2019, nr 3.

Łubocki J.M., Okładka jako część dokumentu na przykładzie płyty gramofonowej w ujęciu bibliologicznym, Warszawa 2017.

Marsh G., Callingham G., Blue Note: Album Cover Art, San Francisco 1991.

Nożyński S., Okólski M., Muzyka bez nośnika? Chmury i strumienie oraz cyfra, taśmy i winyle $w$ walce o pierwostuch lub zapomnienie, „Przegląd Kulturoznawczy” 2019, nr 1, s. 51-67.

Reagan K., Alex Stenweiss. The Inventor of the Modern Album Cover, Köln 2011.

Rychlewski M., Historia rocka według nośników, „Kultura Współczesna” 2009, nr 3.

Rychlewski M., Rewolucja rocka. Semiotyczne wymiary elektrycznej ekstazy, Gdańsk 2011.

Rychlewski M., Rock-kontrkultura - establishment, [w:] Kontrkultura - co nam z tamtych lat?, red. W.J. Burszta, M. Czubaj M. Rychlewski, Warszawa 2005.

Sobczyk I., Mateusz Torzecki, Okładki płyt. Rzecz o wizualnym uniwersum albumów muzycznych, Instytut Kultury Popularnej, Poznań 2015, „Audiosfera. Koncepcje — Badania - Praktyki” 2016, $\mathrm{nr} 4$.

Thorgerson S., Powell A., 100 Best Album Covers, London-New York 1999.

Torzecki M., Okładki plytowe. Rzecz o wizualnym uniwersum albumów muzycznych, Poznań 2015. Torzecki M., Polska okladka płytowa, Poznań 2017.

\section{Źródło audiowizualne}

Blue Note Records: Beyond The Notes, reż. Sophie Huber, 2019.

\section{Źródła internetowe}

Best Buy will stop selling CDs as digital music revenue continues to grow, https://www.theverge. com/2018/2/6/16973538/bestbuy-target-cd-sales-vinyl-cassette.

$J u \dot{~} 100$ mln odbiorców płaci za muzykę w internecie, 6.03.2017, https://www.legalnakultura.pl/ $\mathrm{pl} /$ czytelnia-kulturalna/badania-i-raporty/news/2483,100-mln-odbiorcow-placi-za-muzyke-w -internecie.

Lech F., Oceniaj ptytę po okładce: przygody fonograficzne polskich artystów, https://culture.pl/pl/ artykul/oceniaj-plyte-po-okladce-przygody-fonograficzne-polskich-artystow.

Oktadka jest jak znak drogowy. Rozmowa z jury konkursu 30/30, http://freshmag.pl/magazyn/ lifestyle/3030-wywiad-85.

Rynkowska K., Ach kontrkultura, czyli o okładkach ptyt lat 60. i 70. stów kilka, https://kulturalnemedia.pl/muzyka/kontrkultura-o-okladkach-plyt-60-i-70-slow-kilka.

Z pewnościa jestem zawodowcem - wywiad z Rosławem Szaybo, https://culture.pl/pl/artykul/z -pewnoscia-jestem-zawodowcem-wywiad-z-roslawem-szaybo. 
$* * *$

Krzysztof Niźnik — absolwent kulturoznawstwa na Uniwersytecie Wrocławskim. Zainteresowany przede wszystkim problemami estetyki muzycznej. Uczestniczył w kilku konferencjach naukowych, między innymi „Chopin w kulturze polskiej”, „Współczesne metody nauczania muzyki jazzowej”, „Jazz w kulturze polskiej” (trzy edycje). Autor tekstów o muzyce (między innymi Chopin jako źródto inspiracji polskich muzyków jazzowych, Muzyka w przestrzeni akustycznie ekstremalnej, Miejsce jazzu w polskiej edukacji muzycznej w latach 1960-1990. Postawy, deklaracje, fakty, Wspótczesna ewolucja postaw estetycznych wobec muzyki, czyli o potencjalnych skutkach zawierzenia rzeczywistości wirtualnej). Prowadził w Wałbrzychu autorską audycję radiową poświęconą muzyce jazzowej. Amatorsko zajmuje się fotografią, swoje prace prezentował na kilku wystawach indywidualnych. kryznik@poczta.onet.pl 